\title{
The Use of Nonparametric Quantile Regression and Least Median of Squares Regression for Construction of Growth Curves of Weight
}

\author{
Ağırlıkça Büyüme Eğrilerinin Oluşturulmasında \\ Nonparametrik Kantil Regresyon ve En Küçük \\ Medyan Kareler Regresyonunun Kullanımı
}

\author{
Handan ANKARALI, ${ }^{\mathrm{a}}$ \\ Özge YILMAZ, ${ }^{a}$ \\ Münevver KIZILAY, \\ IIlknur ARSLANOǦLU, \\ Duygu AYDINa
}

Departments of

aBiostatistics,

'Pediatrics,

Düzce University Faculty of Medicine, Düzce

Geliş Tarihi/Received: 15.05 .2012

Kabul Tarihi/Accepted: 04.12.2012

The abstract of this study was published in the Proceedings Book of XII. National Biostatistics Congress, 28 June-1 July 2010, Van, Turkey

Yazışma Adresi/Correspondence: Handan ANKARALI

Düzce University Faculty of Medicine, Department of Biostatistics, Düzce, TÜRKIYETTURKEY

hankarali@yahoo.com

\begin{abstract}
Objective: This study aimed to investigate the use of the Least Median Squares (LMS) regression and nonparametric quantile regression model comparatively to describe children's weight growth. Material and Methods: Two different models were used to obtain the percentile curves to identify the weight growth in girls. The first model was obtained by LMS regression, which is a member of the family of nonlinear parametric quantile regression. In addition, in this model percentile curves used to define growth were generated using the Box-Cox transformation and the cubic spline. The second model was obtained by nonparametric quantile regression that did not require the assumption of a normal distribution for construction of percentile curves. This method is a flexible approach, as well as being computationally simple. The weight values obtained from 1771 healthy girls aged between 6 and 14 years were used in both methods. The data were collected from the cross-sectional study conducted in schools in Düzce city. Results: The distributions of weight measurements according to ages revealed that there were deviations from normality at some ages, there were deviated values in the tail regions of the distribution, and the variances changed according to ages. Using both methods, growth curves were constructed separately for each age group. Predicted values of the LMS and the non-parametric quantile regression models were similar for each age. In addition, the error sum of squares derived from non-parametric quantile regression was lower than that derived from LMS regression for each percentile curve. Moreover, the estimations obtained from both methods were highly correlated with the estimation values of the province Istanbul, which was considered the reference. Conclusion: When the assumptions about the distribution and variances of the data are violated and these assumptions cannot be achieved with the transformation, nonparametric quantile regression method gives more reliable results for the creation of percentile curves.
\end{abstract}

Key Words: Growth\&development; growth charts

ÖZET Amaç: Bu çalı̧̧mada, çocuklardaki ağırlıkça büyümeyi tanımlamada, En Küçük Medyan Kareler (LMS) regresyonu ve nonparametrik kantil regresyon modellerinin karșlaştırmalı olarak incelenmesi amaçlanmıștur Gereç ve Yöntemler: Çalıșmada, kız çocuklarının ağırlıkça büyümesini tanımlamak için persentil eğrilerinin elde edilmesinde iki farkh büyüme modeli kullanılmıștur. Bu yöntemlerden birisi olan LMS regresyonu, doğrusal olmayan parametrik kantil regresyon ailesinden olup, Box-Cox transformasyonu ve kübik eğri yardımıyla persentil eğrilerini oluşturur. Ikinci yöntem, LMS yöntemine alternatif olabilecek ve dağlım ön şartı gerektirmeyen nonparametrik kantil regresyondur. Bu yöntem, hesaplama kolayliklarının yanı sıra esnek bir yaklaşımdır. Her iki yöntemin uygulamasında, yaşlan 6 ile 14 arasında değișen toplam 1771 sağlıkłı kız çocuğundan elde edilen ağırlık değerleri kullanılmıștır. Bu veriler, Düzce ilindeki okullarda yürütülen kesitsel bir çalışmaya aittir. Bulgular: Yaşlara göre ağırlık ölçümlerinin dağılımı incelendiğinde, bazı yaşlarda normal dağılımdan sapmaların gözlendiği, dağlımın kuyruk bölgelerinde sapan değerlerin olduğu ve varyansların yaşlara göre değiștiği belirlenmiștir. Her iki yöntem yardımıyla, her bir yaş grubu için ayn ayn büyüme eğrileri olușturulmuştur. Bu eğrilerden elde edilen tahmini ağırlık değerleri birbirine benzer çıkmıştır. Bunun yanı sıra oluşturulan her bir persentil eğrisi için parametrik olmayan kantil regresyon tahminlerinin hatası, LMS yöntemine göre daha küçük bulunmuștur. Aynca her iki yöntem sonucunda elde edilen tahminlerin, referans olarak kabul edilen Istanbul ili tahmin değerleri ile hayli kuvvetli bir ilişki içinde olduğu belirlenmiștir. Sonuç: Verilerin dağılımı ve varyanslar ile ilgili varsayımlann bozulduğu durumlarda ve transformasyonla bu varsayımların sağlanamadı̆̆ı koşullarda, nonparametrik kantil regresyon metodu, persentil eğrilerinin olușturulmasında daha güvenilir sonuçlar vermektedir.

Anahtar Kelimeler: Büyüme ve gelișme; büyüme gözlem kartlan 
G rowth is expressed as a structural increase and is defined as an increase of body volume and mass with the increase of number and size of cells. ${ }^{1}$ Various growth models have been used to describe the growth occurring in different physical dimensions or organs of the human body and to reveal whether the current growth is healthy growth. Some of them focus on the mean and the others are able to describe the entire conditional distribution of the dependent variable (logistic nonlinear mixed model). Moreover, these models are classified as linear and nonlinear models or parametric, semi-parametric, and non-parametric growth models. ${ }^{1,2}$

Quantile regression $(\mathrm{QR})$ techniques are widely used in preliminary medical diagnosis to identify unusual subjects in the sense that the value of some particular measurement lies in one or another tail of the appropriate reference distribution. QR can therefore help us to obtain a more complete picture of the underlying relationship between outcome such as weight and covariate such as age. $Q R$ results are characteristically robust to outliers and heavy-tailed distributions. ${ }^{3-5}$

Least Median Squares (LMS) method belongs to the family of nonlinear semi-parametric quantile regression and is a generalized form for the determined quantiles of median regression. Recently some alternative methods have been developed to LMS, which have insufficient results, and one of those is the nonparametric quantile regression (NPQR) model. 6,7

This study aimed to compare the use of LMS regression model and nonparametric quantile regression model to describe the weight growth of a healthy child.

\section{MATERIAL AND METHODS}

\section{LMS METHOD}

The distribution of the outcome variable changes according to age is shown by the reference centile curves. The changing distribution of three curves representing the median $(M)$, coefficient of variation (S), and skewness ( $\mathrm{L}$ or $\lambda)$, which is expressed as a Box-Cox power, are summarized by the LMS method. Three curves (L, M, and S) can be fitted as cubic splines with non-linear regression using penalized likelihood, and the amount of smoothing needed can be given in terms of smoothing parameters or equivalent degrees of freedom. These parameters can be interpreted as the dimensionality of the fitted function and are measured by computing the trace of the pseudo-projection matrix defining the estimator. ${ }^{6,8}$ In the selection of appropriate effective degrees of freedom (edf) value, the changes in the Deviance and Akaike Information Criteria (AIC) values are considered. The curves are created by taking combinations of L, M, S where Deviance or AIC values have the smallest number. The edf values that give good results in many circumstances for L, M, S parameters, are 3, 5, 3 respectively.

LMS method selects appropriate $\lambda$, applies Box-Cox transformation according to this lambda and transforms $\mathrm{Y}(\mathrm{t})$ 's measurements to standardized $\mathrm{Z}(\mathrm{t}$ ) values to ensure normality. The transformed observations are independent and normally distributed with constant variance. ${ }^{9}$

$$
\mathrm{Z}(\mathrm{t})=\frac{\left[\begin{array}{l}
\mathrm{Y}(\mathrm{t}) \\
\mu(\mathrm{t})
\end{array}\right]^{\lambda(\tau)}-1}{\lambda(\tau) \sigma(\mathrm{t})}
$$

After transformation, quantile curve for $\alpha €$ $[0,1]$ is estimated by the following model.

$\mathrm{Q}(\alpha \mathrm{It})=\mu(\mathrm{t})\left[1+\lambda(\mathrm{t}) \sigma(\mathrm{t}) \phi^{-1}(\alpha)\right]^{1 / 2(\mathrm{t})}$

In this equation;

$\alpha$ : The lower tail area of the centile,

$z_{\alpha}$ : The normal equivalent deviate of size $\alpha .{ }^{9,10}$

A main assumption of the LMS method is that the data are normally distributed. The main problem about the assumption may be the presence of kurtosis, which could not be adjusted with transformation. However, kurtosis tends to be less important than skewness as a contributor to nonnormality. ${ }^{6}$

When the assumptions of normality and the constancy of the variance of outcome variable are not valid, NPQR method is preferred instead of LMS for construction of growth charts. ${ }^{11}$ 


\section{NONPARAMETRIC QUANTILE REGRESSION}

Various non-parametric quantile regression NPQR tools have been proposed in the literature. ${ }^{11-14}$ Nonparametric spline-based quantile regression is a flexible approach, as well as being computationally simple, allowing a different grade of curvature for each conditional quantile. ${ }^{13}$

Kernel, Local polynomials or smoothing splines are used for smoothing the percentile curves predicted in NPQR method. We used series estimators, which are constructed based on cubic $B$-splines. These splines directly extend linear and low order polynomial models. To generate $B$-splines, $\mathrm{n}$, $\mathrm{m}$, and $\mathrm{p}$ values are needed. Here, $\mathrm{p}$ is the degree of B-spline, $n+1$ is the number of control points, $m$ is the number of basic functions and $m=n+p+1$. In general, the lower the degree, the closer a $B$-spline

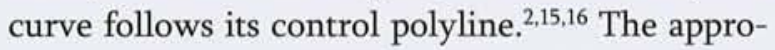
ximation abilities of $B$-splines are well known from the theoretical standpoint; spline models retain the advantages of algebraic polynomials. Iterative steps are used for smoothing and appropriate smoothing coefficient is determined by error of model in each iteration and proximity to each other of coefficients estimated for each smoothing parameter. Smoothing parameters are estimated by reweighted least square method iteratively.

In the NPQR method, the quantiles are estimated as a linear combination of multiple basis function. ${ }^{16}$

\section{DATA}

Weight is one of the most important indicators for growth of children and adolescents. The distribution of weight and changes in variances of weights are important issues for the selection of suitable growth curve in each age group. ${ }^{16}$

The data were obtained from a cross-sectional study carried out in Düzce city, located in the northwest of Turkey with a heterogeneous sociocultural structure. Therefore weights were measured only once from each subject in each age group. Schools were selected by stratified sampling method according to income level. Weights were measured twice in 770 girls from high-income schools, 288 girls in middle income schools and 713 girls in low-income schools. The arithmetic mean of the two measurements were recorded. Weights were measured with precision digital scales (Felix brand), which are sensitive to $0.1 \mathrm{~kg}$. In summary, the data set consisted of the body weight measurements of 1771 healty Turkish girls aged between 6 and 14 years, in Düzce city between 2009 and 2010. The study was approved by the ethical committee of the university.

In this study, unconditional growth curves were constructed for each age by using LMS and NPQR. However, other covariates (other socialdemographic features) were not considered to build these curves.

Fitting of the percentile curves was performed using the LMS Chart Maker Ligth software program (version 2.3; The Institute of Child Health, London) and $R$ [is a public domain language for data analysis sustained by the R Development Core Team (2004)]. $R$ commands for LMS and NPQR methods were given in the Appendix section.

\section{RESULTS}

\section{DESCRIPTIVE VALUES}

Mean, median, standard deviation (SD), minimum , and maximum values were given in Table 1 . The proportional distribution of age groups were as follows: $6.21 \%$ of subjects were 6 years-old, $13.15 \%$ were 7 years-old, $12.93 \%$ were 8 years-old, $12,87 \%$ were 9 years-old, $11.85 \%$ were 10 years-old, $14.54 \%$ were 11 years-old, $13.21 \%$ were 12 yearsold, $11.57 \%$ were 13 years-old, and $3.71 \%$ were 14 years-old. Although the rate of 6 and 14 years-old children was smaller than the rate of other age groups, the sample sizes of those two age groups was not too small. The standard deviation seemed to increase with age (Table 1).

Percentile values of this study were frequently used to identify human growth percentile values (Table 2).

The distribution of weights according to ages, revealed that the weight values of the girls who were 8,9 and 11 years old were close to the deviation from normality. In contrast, the values in the other age groups were distributed normally (Table 2). 


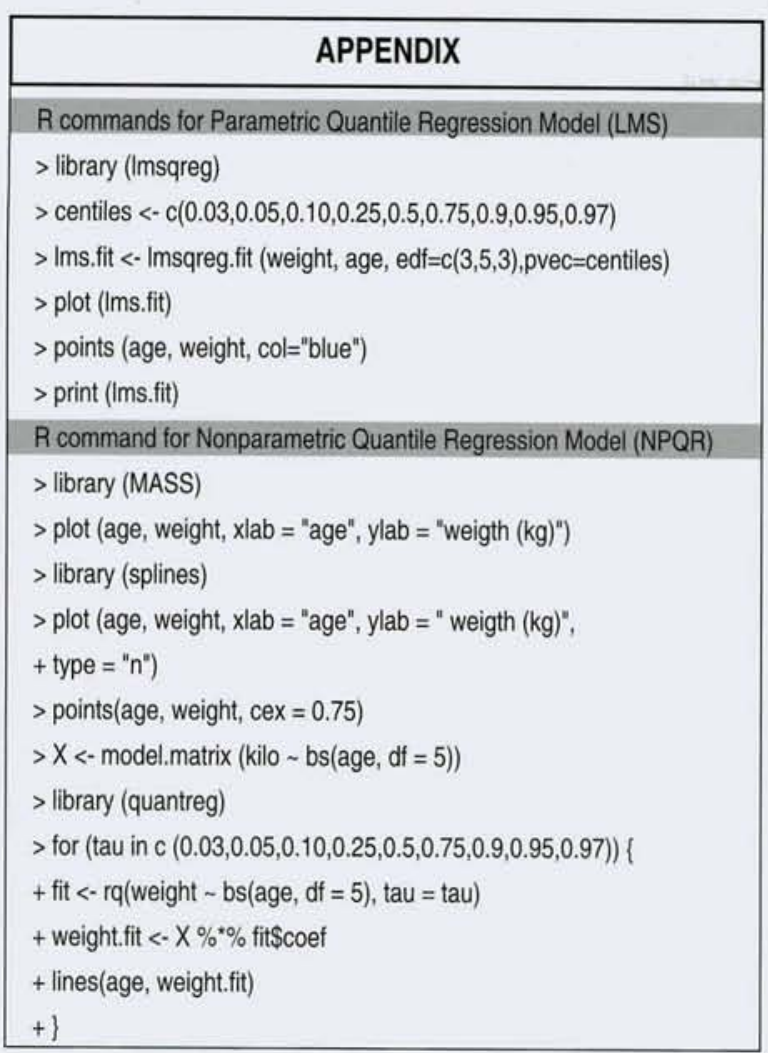

Table 3 showed that skewness and kurtosis coefficients of weight values of the girls between 7 and 11 years-old showed more deviation than the normal distribution values. These results were compatible with the normality test in Table 2. Moreover, the variances at different ages were heterogeneous, leading to the conclusion that variances are not stable (Figure 1).

On the other side, the raw percentile curves, which were not transformed and not smoothed according to age were given in Figure 2. The percentile values that were taken into consideration, are important in health literature. Because of violations of the assumptions for parametric tests, firstly Box-Cox transformation was applied to the data. And then percentile curves were constructed with the LMS method.

\section{RESULTS OF LMS METHOD}

Weight values deviated from normal distribution at some ages and deviated values existed in tails of distribution. In addition, the variances changed according to age. Since these assumptions were damaged, the LMS method that includes Box-Cox transformation was used. The corrected percentile curves, that were predicted according to ages after the LMS method was applied, and the L, M, S estimation curves were given in Figure 3.

\begin{tabular}{|ccccccc|}
\hline \multicolumn{7}{|c|}{ TABLE 1: Descriptive statistics of weights. } \\
\hline Age & N & Mean & Median & SD & Minimum & Maximum \\
\hline 6 & 110 & 22,248 & 21,800 & 2,752 & 16,400 & 30,000 \\
\hline 7 & 233 & 24,913 & 24,800 & 3,816 & 17,200 & 38,800 \\
\hline 8 & 229 & 27,303 & 26,600 & 4,874 & 18,600 & 43,800 \\
\hline 9 & 228 & 30,937 & 30,200 & 5,585 & 21,400 & 47,400 \\
\hline 10 & 210 & 35,554 & 34,800 & 6,804 & 23,200 & 57,200 \\
\hline 11 & 256 & 39,324 & 38,400 & 7,778 & 25,200 & 66,400 \\
\hline 12 & 234 & 46,523 & 45,500 & 8,565 & 28,800 & 77,000 \\
\hline 13 & 205 & 49,908 & 49,200 & 8,648 & 30,600 & 76,800 \\
\hline 14 & 66 & 53,324 & 51,700 & 8,109 & 39,200 & 75,200 \\
\hline
\end{tabular}

$\mathrm{N}$ : Number; SD: Standard deviation.

\begin{tabular}{|c|c|c|c|c|c|c|c|c|c|c|}
\hline \multirow[b]{2}{*}{ Age } & \multirow[b]{2}{*}{3} & \multicolumn{7}{|c|}{ Percentile values } & \multicolumn{2}{|c|}{ Normality test } \\
\hline & & 5 & 10 & 25 & 50 & 75 & 90 & 95 & 97 & (P) \\
\hline 6 & 17,600 & 17,820 & 18,620 & 20,350 & 21,800 & 23,850 & 25,580 & 27,870 & 28,734 & 0,587 \\
\hline 7 & 19,004 & 19,570 & 20,200 & 22,200 & 24,800 & 26,800 & 29,800 & 32,530 & 33,396 & 0,169 \\
\hline 8 & 20,360 & 21,000 & 21,600 & 24,000 & 26,600 & 29,400 & 34,600 & 37,500 & 40,220 & 0.05 \\
\hline 9 & 23,148 & 23,690 & 24,400 & 26,600 & 30,200 & 34,500 & 39,200 & 42,110 & 43,478 & 0,066 \\
\hline 10 & 25,798 & 26,600 & 27,400 & 30,350 & 34,800 & 39.000 & 45,100 & 48,360 & 52,268 & 0.108 \\
\hline 11 & 28,342 & 28,600 & 30,140 & 33,600 & 38,400 & 44,150 & 50,400 & 53,010 & 57,000 & 0,073 \\
\hline 12 & 32,620 & 33,800 & 36,000 & 40,350 & 45,500 & 52,050 & 58,700 & 61,650 & 63,580 & 0,318 \\
\hline 13 & 34,636 & 36,520 & 40,440 & 43,900 & 49,200 & 55,100 & 61,800 & 65,600 & 68,476 & 0,269 \\
\hline 14 & 41,208 & 42,140 & 44,340 & 46,750 & 51,700 & 57,550 & 66,080 & 69,190 & 69,994 & 0,633 \\
\hline
\end{tabular}




\begin{tabular}{|c|c|c|c|c|}
\hline \multirow{2}{*}{ Age } & \multirow[b]{2}{*}{ Skewness \pm S.E. } & \multirow[b]{2}{*}{ Kurtosis $\pm S . E$} & \multicolumn{2}{|c|}{$\begin{array}{l}\text { Levene test for Homogenity of variance } \\
\qquad \text { (df1=8, df2=1762) }\end{array}$} \\
\hline & & & Test statistics & $P$ value \\
\hline 6 & $0,474 \pm 0,230$ & $0,151 \pm 0,457$ & 33,292 & 0,0001 \\
\hline 7 & $0,792 \pm 0,159$ & $1,000 \pm 0,318$ & & \\
\hline 8 & $1,022 \pm 0,161$ & $1,074 \pm 0.320$ & & \\
\hline 9 & $0,729 \pm 0,161$ & $0,030 \pm 0,321$ & & \\
\hline 10 & $0,728 \pm 0,168$ & $0,315 \pm 0,334$ & & \\
\hline 11 & $0,697 \pm 0,152$ & $0,274 \pm 0,303$ & & \\
\hline 12 & $0,478 \pm 0,159$ & $0,054 \pm 0,317$ & & \\
\hline 13 & $0,413 \pm 0,170$ & $0,111 \pm 0,338$ & & \\
\hline 14 & $0,637 \pm 0,295$ & $-0,194 \pm 0,582$ & & \\
\hline
\end{tabular}

SE: Standard error.

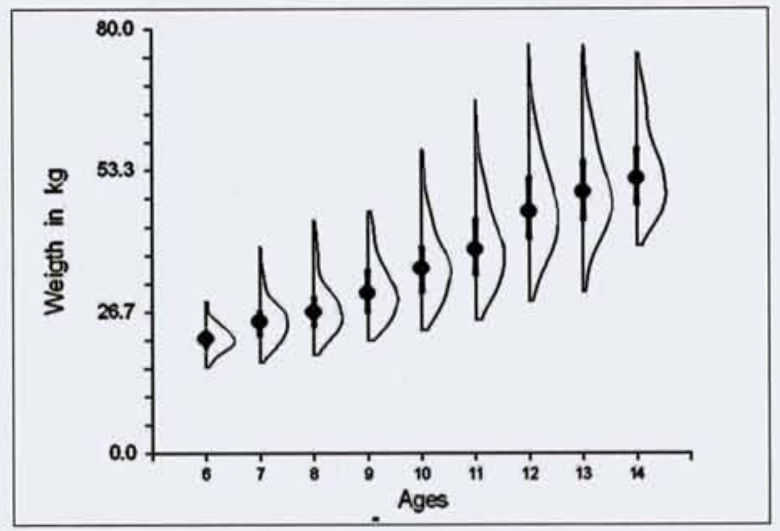

FIGURE 1: Distribution of weight values of girls at each age.

While there was a linear increase in $\mathrm{L}$ and $\mathrm{M}$ values in Figure 3, S value seemed to increase until the age $10-11$ years followed by a decreasing trend later. The blue spots in the graphic show real weight values and the discontinuous lines shows the percentile curves that are estimated with LMS.

The percentile values that were estimated with LMS method were given in Table 4. These values were obtained after both transformation and smoothing.

In Table 5, the estimated values of $\mathrm{L}, \mathrm{M}$, and $\mathrm{S}$ parameters according to ages were shown. Percentile values were estimated by using these values.

\section{RESULTS OF NONPARAMETRIC QUANTILE REGRESSION}

Percentile curves were reconstructed by using nonparametric quantile regression on the same data be-

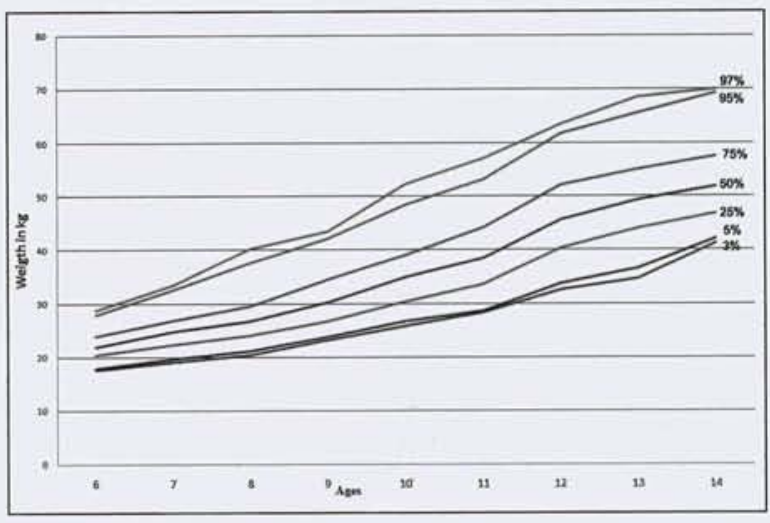

FIGURE 2: Raw percentile values in each group.

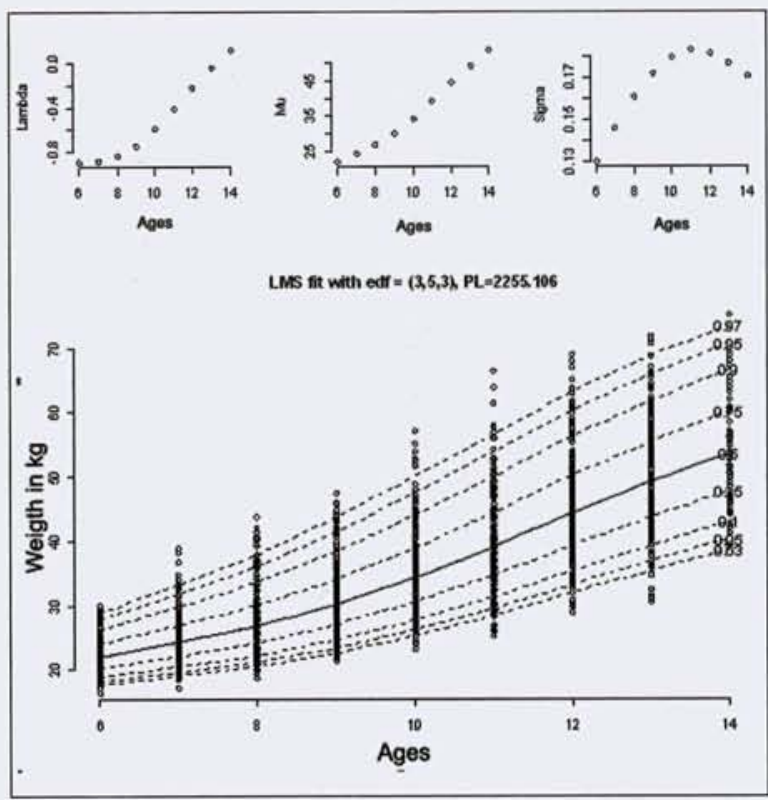

FIGURE 3: Predicted percentile curves according to the LMS method. 


\begin{tabular}{|c|c|c|c|c|c|c|c|c|c|}
\hline \multirow[b]{2}{*}{ Age } & \multicolumn{9}{|c|}{$\begin{array}{l}\text { LMS } \\
\text { Predicted Percentile Values }\end{array}$} \\
\hline & 3 & 5 & 10 & 25 & 50 & 75 & 90 & 95 & 97 \\
\hline 6 & 17,627 & 18,080 & 18,823 & 20,202 & 21,979 & 24,077 & 26,320 & 27,861 & 28,958 \\
\hline 7 & 18,999 & 19,539 & 20,428 & 22,099 & 24,285 & 26,920 & 29,797 & 31,813 & 33,266 \\
\hline 8 & 20,468 & 21,102 & 22,152 & 24,141 & 26,774 & 29,994 & 33,567 & 36,105 & 37,952 \\
\hline 9 & 22,562 & 23,319 & 24,577 & 26,964 & 30,137 & 34,030 & 38,360 & 41,440 & 43,682 \\
\hline 10 & 25,209 & 26,124 & 27,640 & 30,510 & 34,301 & 38,908 & 43,965 & 47,517 & 50,077 \\
\hline 11 & 28,309 & 29,409 & 31,225 & 34,631 & 39,067 & 44,350 & 50,012 & 53,901 & 56,659 \\
\hline 12 & 31,923 & 33,225 & 35,360 & 39,318 & 44,371 & 50,245 & 56,367 & 60,470 & 63,332 \\
\hline 13 & 35,369 & 36,854 & 39,271 & 43,687 & 49,209 & 55,467 & 61,813 & 65,971 & 68,827 \\
\hline 14 & 38,694 & 40,341 & 42,999 & 47,790 & 53,662 & 60,168 & 66,612 & 70,755 & 73,567 \\
\hline
\end{tabular}

LMS: Least median of squares.

cause there was deviation in tails of distribution even if Box-Cox method was applied. The percentile values that were estimated by the NPQR method were given in Table 6 .

The percentile curves for the NPQR method were illustrated in Figure 4. In the figure, symmetric percentile curves were shown with the same color. The effect of covariate (age) occured differently on different percentile curves in both LMS and NPQR methods because the estimated percentile curves were not exactly parallel to each other.

The results of symmetric percentiles were given in Tables 7-11, which involves NPQRL model coefficients for each percentile values. 'bs' is the ba-

\begin{tabular}{|lccc|}
\hline \multicolumn{4}{|c|}{ TABLE 5: $\mathrm{L}, \mathrm{M}$ and S values at each age. } \\
\hline Age & $\mathrm{L}$ & $\mathrm{M}$ & $\mathrm{S}$ (Coeff. Var.) \\
\hline 6 & $-0,903$ & 21,978 & 0,130 \\
\hline 7 & $-0,891$ & 24,285 & 0,146 \\
\hline 8 & $-0,852$ & 26,774 & 0,160 \\
\hline 9 & $-0,755$ & 30,138 & 0,172 \\
\hline 10 & $-0,602$ & 34,302 & 0,180 \\
\hline 11 & $-0,414$ & 39,067 & 0,183 \\
\hline 12 & $-0,226$ & 44,372 & 0,182 \\
\hline 13 & $-0,048$ & 49,209 & 0,177 \\
\hline 14 & 0,112 & 53,662 & 0,171 \\
\hline
\end{tabular}

se function and all the models constitute of 5 base functions. " $\mathrm{B}$ " is the regression coefficient of the base function and in the next column standard er-

TABLE 6: Smoothing percentile values obtained from NPQR model.

\begin{tabular}{|c|c|c|c|c|c|c|c|c|c|}
\hline \multirow[b]{2}{*}{ Age } & \multicolumn{9}{|c|}{$\begin{array}{c}\text { NPQR } \\
\text { Predicted Percentile Values }\end{array}$} \\
\hline & 3 & 5 & 10 & 25 & 50 & 75 & 90 & 95 & 97 \\
\hline 6 & 17,60 & 18,40 & 18,80 & 20,40 & 22,00 & 24,00 & 25,40 & 27,60 & 28,60 \\
\hline 7 & 18,85 & 19,21 & 20,00 & 22,00 & 24,40 & 26,80 & 29,80 & 32,50 & 33,25 \\
\hline 8 & 20,80 & 21,20 & 22,00 & 24,00 & 26,99 & 29,80 & 34,27 & 37.08 & 39,20 \\
\hline 9 & 23,13 & 23,68 & 24,40 & 26,50 & 30,20 & 33,65 & 39,20 & 42,07 & 44,80 \\
\hline 10 & 25,60 & 26,20 & 27,03 & 29,72 & 34,34 & 38,80 & 44,84 & 48,00 & 50,75 \\
\hline 11 & 28,40 & 29,20 & 30,60 & 34,00 & 39,34 & 44,91 & 50,94 & 54,53 & 57,00 \\
\hline 12 & 31,80 & 33,13 & 35,62 & 39,40 & 44,80 & 51,20 & 57,00 & 61,00 & 63,20 \\
\hline 13 & 36,00 & 37,60 & 40,80 & 44,28 & 49,40 & 55,85 & 62,00 & 66,70 & 67,91 \\
\hline 14 & 41,20 & 42,00 & 44,40 & 46,60 & 51,60 & 56,80 & 64,80 & 68,80 & 69,40 \\
\hline
\end{tabular}

NPQR: Nonparametric quantile regression. 


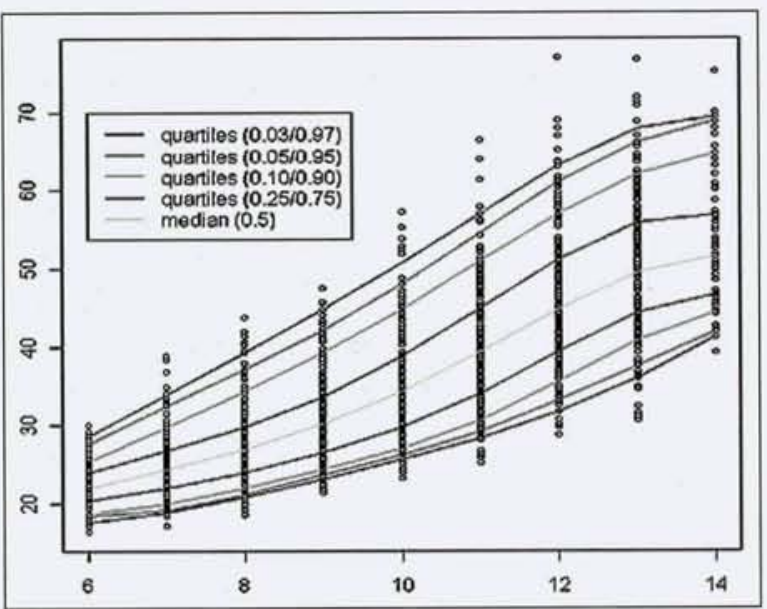

FIGURE 4: Predicted percentile curves for the nonparametric quantile regression (NPQR) method.

ror of that coefficient. Next column of the table indicates standart error of $B$ coefficient. $t$ value shows the hypothesis test of the B coefficient. The intercept value is equal to the minimum weight value in the percentile. Percentile value of a new subject is estimated by using the intercept value and the regression coefficients.
Table 12 includes the mean error of the models, and standard deviation of those errors with minimum and maximum values. Errors were computed by summing the squares of the differences between the estimated values from the LMS and NPQR models and their observed weight values. This table revealed that the sum of error squares of the NPQR estimates was lower than the LMS estimates in all percentile values. Especially this difference was highest at a percentile value of $10 \%$. This result indicated that the estimations of NPQR method were more successful (Table 12).

The studies that are conducted in İstanbul constitute the basis of growth curves that are developed in Turkish children. Neyzi et al. ${ }^{17}$ described the reference values for various percentile values of girls aged between 12-14 years (Table 13). These values were obtained via the LMS method. When the reference values described by Neyzi et al. ${ }^{17}$ were compared with the LMS estimations (Table 4) and NPQR estimations (Table 6), similar results were obtained.

\begin{tabular}{|c|c|c|c|c|c|c|c|c|}
\hline \multirow[b]{2}{*}{ Model coefficients } & \multicolumn{4}{|c|}{ Model coefficients for 3 . percentile } & \multicolumn{4}{|c|}{ Model coefficients for 97 . percentile } \\
\hline & B & Std. Error & $\mathrm{t}$ value & $\operatorname{Pr}(>|t|)$ & B & Std. Error & $\mathrm{t}$ value & $\operatorname{Pr}(>|t|)$ \\
\hline (Intercept) & 17.6 & 0.2653 & 66.33881 & 0 & 28.6 & 0.40026 & 71.45442 & 0 \\
\hline bs(age, df = 5) 1 & 0.78279 & 0.76576 & 1.02224 & 0.30681 & 5.23904 & 2.05577 & 2.54846 & 0.0109 \\
\hline bs(age, $d f=5) 2$ & 4.68415 & 1.16665 & 4.01504 & 0.00006 & 13.89144 & 3.04651 & 4.55979 & 0.00001 \\
\hline bs (age, $d f=5) 3$ & 11.20669 & 1.7237 & 6.50151 & 0 & 30.30452 & 3.19347 & 9.48952 & 0 \\
\hline bs(age, $d f=5) 4$ & 17.83722 & 2.68745 & 6.63724 & 0 & 41.48217 & 3.89841 & 10.64079 & 0 \\
\hline bs(age, $d f=5) 5$ & 23.6 & 2.33766 & 10.09558 & 0 & 40.8 & 1.10715 & 36.85129 & 0 \\
\hline
\end{tabular}

B: Regression coefficient of the base function; NPQR: Nonparametric quantile regression; $\operatorname{Pr}(>|t| t)$ : Actual $p$ value.

\begin{tabular}{|c|c|c|c|c|c|c|c|c|}
\hline \multirow[b]{2}{*}{ Model coefficients } & \multicolumn{4}{|c|}{ Model coefficients for 5 . percentile } & \multicolumn{4}{|c|}{ Model coefficients for 95 . percentile } \\
\hline & B & Std. Error & $\mathrm{t}$ value & $\operatorname{Pr}(>|t|)$ & B & Std. Error & $\mathrm{t}$ value & $\operatorname{Pr}(>|t|)$ \\
\hline (Intercept) & 18.4 & 0.46745 & 39.36284 & 0 & 27.6 & 1.17017 & 23.58634 & 0 \\
\hline bs(age, $d f=5) 1$ & 0.0028 & 0.98809 & 0.00283 & 0.99774 & 5.30435 & 2.48221 & 2.13695 & 0.03274 \\
\hline bs (age, $d f=5) 2$ & 4.62928 & 0.90399 & 5.12095 & 0 & 11.51232 & 2.44075 & 4.71672 & 0 \\
\hline bs $($ age,$d f=5) 3$ & 10.81077 & 1.27702 & 8.46561 & 0 & 29.08565 & 3.3393 & 8.7101 & 0 \\
\hline$b s(a g e, d f=5) 4$ & 19.4362 & 1.75624 & 11.06693 & 0 & 40.34435 & 2.8138 & 14.33805 & 0 \\
\hline bs(age, $d f=5) 5$ & 23.6 & 1.16034 & 20.33878 & 0 & 41.2 & 2.04663 & 20.13061 & 0 \\
\hline
\end{tabular}

B: Regression coefficient of the base function; bs: Base function; df: Difference; NPQR: Nonparametric quantile regression; $\operatorname{Pr}(>|t|)$ : Actual $p$ value. 


\begin{tabular}{|c|c|c|c|c|c|c|c|c|}
\hline \multirow[b]{2}{*}{ Model coefficients } & \multicolumn{4}{|c|}{ Model coefficients for 10 . percentile } & \multicolumn{4}{|c|}{ Model coefficients for 90 . percentile } \\
\hline & B & Std. Error & $\mathrm{t}$ value & $\operatorname{Pr}(>|t|)$ & B & Std. Error & t value & $\operatorname{Pr}(>|t|)$ \\
\hline (Intercept) & 18.8 & 0.491 & 38.2889 & 0 & 25.4 & 0.70229 & 36.16737 & 0 \\
\hline bs(age, $d f=5) 1$ & 0.66805 & 0.98684 & 0.67695 & 0.49852 & 4.49177 & 2.35082 & 1.91072 & 0.0562 \\
\hline bs(age, $d f=5) 2$ & 4.77571 & 0.81647 & 5.84919 & 0 & 11.1996 & 2.51131 & 4.45967 & 0.00001 \\
\hline bs(age, $d f=5) 3$ & 11.36023 & 1.20989 & 9.3895 & 0 & 27.52696 & 2.2648 & 12.15425 & 0 \\
\hline bs(age, $d f=5) 4$ & 23.36828 & 1.73096 & 13.50019 & 0 & 38.08063 & 2.59948 & 14.64933 & 0 \\
\hline bs(age, df $=5) 5$ & 25.6 & 1.36196 & 18.79646 & 0 & 39.4 & 2.58122 & 15.26411 & 0 \\
\hline
\end{tabular}

B: Regression coefficient of the base function; bs: Base function; dt: Difference; NPQR: Nonparametric quantile regression; $\operatorname{Pr}(>|t|)$ : Actual $p$ value.

\begin{tabular}{|c|c|c|c|c|c|c|c|c|}
\hline \multirow[b]{2}{*}{ Model coefficients } & \multicolumn{4}{|c|}{ Model coefficients for 25. percentile } & \multicolumn{4}{|c|}{ Model coefficients for 75 . percentile } \\
\hline & B & Std. Error & t value & $\operatorname{Pr}(>|t|)$ & B & Std. Error & $t$ value & $\operatorname{Pr}(>|t|)$ \\
\hline (Intercept) & 20.4 & 0.22347 & 91.28936 & 0 & 24 & 0.37096 & 64.69689 & 0 \\
\hline bs(age, $d f=5) 1$ & 1.43838 & 0.64853 & 2.21791 & 0.02669 & 2.91646 & 0.93504 & 3.11907 & 0.00184 \\
\hline bs(age, $d f=5) 2$ & 4.54785 & 0.93105 & 4.88462 & 0 & 6.65378 & 1.26115 & 5.27598 & 0 \\
\hline bs $($ age, $d f=5) 3$ & 13.72472 & 1.0978 & 12.50207 & 0 & 22.62521 & 1.8715 & 12.08937 & 0 \\
\hline bs(age, $d f=5) 4$ & 25.85018 & 1.10155 & 23.4672 & 0 & 34.38789 & 2.06874 & 16.62264 & 0 \\
\hline bs(age, $d f=5) 5$ & 26.2 & 0.70188 & 37.32829 & 0 & 32.8 & 2.06976 & 15.84727 & 0 \\
\hline
\end{tabular}

B: Regression coefficient of the base function; bs: Base function; df: Difference; NPQR: Nonparametric quantile regression; $\operatorname{Pr}(>|t|)$ : Actual $p$ value.

The relationship between the reference valu$\mathrm{es}^{17}$ and the estimated values obtained in the present study was given in Table 14 collectively. Table 14 revealed that there was a significant and very strong relationship between reference values ${ }^{17}$ and the estimation values obtained by the LMS and $\mathrm{NPQR}$ methods in the present study.

\section{DISCUSSION}

Many studies have defined human growth in the medical research literature. ${ }^{6,8,17-21}$ Observing growth stages is a very important process for understanding whether the development of children is healthy or not. Assessment of children's growth is monitored by using percentile curves that are developed for weight, height and head circumference measurements according to the age and gender.

In this study, percentile curves were constructed using weight data of healthy girls by using the LMS and NPQR methods where the distribution of weight values was skewed and the variance of the

\begin{tabular}{|lcccc|}
\hline TABLE 11: NPQR model coefficients for $50^{\text {th }}$ percentile. \\
\hline \multicolumn{5}{c}{ Model coefficients for 50 . percentile } \\
Model coefficients & B & Std. Error & $t$ value & $\operatorname{Pr}(>|t|)$ \\
\hline (Intercept) & 22 & 0.35468 & 62.02722 & 0 \\
\hline bs(age, $d f=5) 1$ & 2.4435 & 0.86432 & 2.82707 & 0.00475 \\
\hline bs(age, $d f=5) 2$ & 5.94821 & 0.9659 & 6.15819 & 0 \\
\hline bs(age, $d f=5) 3$ & 18.4484 & 1.22 & 15.12163 & 0 \\
\hline bs(age, $d f=5) 4$ & 29.11412 & 1.42472 & 20.43498 & 0 \\
\hline$b s($ age, $d f=5) 5$ & 29.6 & 1.17999 & 25.08489 & 0 \\
\hline
\end{tabular}

B: Regression coefficient of the base function; bs: Base function; df: Difference; NPQR: Nonparametric quantile regression; $\operatorname{Pr}(>|t|)$ : Actual $p$ value.

weights varied according to age. Some researchers have emphasized that the quantile regression model gives better results in such circumstances. ${ }^{22}$ The results of the Monte Carlo simulation study showed that non-parametric quantile regression methods might provide better and more robust estimation results especially when the underlying model was non-linear and/or the error term followed a non-normal distribution compared to their parametric counterparts. ${ }^{23}$ 


\begin{tabular}{|c|c|c|c|c|c|c|c|}
\hline \multicolumn{2}{|c|}{ Percentile } & \multirow{2}{*}{$\begin{array}{l}\mathrm{N} \\
9\end{array}$} & \multirow{2}{*}{$\begin{array}{c}\text { Mean Error } \\
-0.325\end{array}$} & \multirow{2}{*}{$\begin{array}{c}\text { Std. Dev. } \\
0.734\end{array}$} & \multirow{2}{*}{$\begin{array}{c}\text { Sum of error square } \\
5.264\end{array}$} & \multirow{2}{*}{$\begin{array}{c}\text { Minimum } \\
-1.881\end{array}$} & \multirow{2}{*}{$\begin{array}{c}\text { Maximum } \\
0.733\end{array}$} \\
\hline & 3 & & & & & & \\
\hline हू & 5 & 9 & -0.177 & 0.704 & 4.246 & -1.645 & 0.809 \\
\hline 昰 & 10 & 9 & -0.067 & 0.794 & 5.082 & -1.282 & 1.085 \\
\hline$\sum_{j}^{01}$ & 25 & 9 & -0.052 & 0.593 & 2.84 & -1.032 & 1.031 \\
\hline$\stackrel{\mathscr{E}}{E}$ & 50 & 9 & -0.131 & 0.518 & 2.298 & -1.129 & 0.667 \\
\hline "̄ & 75 & 9 & -0.021 & 0.753 & 4.534 & -1.805 & 0.674 \\
\hline 을 & 90 & 9 & -0.411 & 1.08 & 10.843 & -2.333 & 1.282 \\
\hline 嵒 & 95 & 9 & -0.212 & 1.015 & 8.648 & -1.395 & 1.645 \\
\hline & 97 & 9 & -0.28 & 1.284 & 13.891 & -2.268 & 1.881 \\
\hline \multirow{9}{*}{ 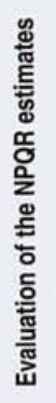 } & 3 & 9 & $-0,074$ & 0,586 & 2,793 & $-1,364$ & 0,820 \\
\hline & 5 & 9 & $-0,098$ & 0,567 & 2,661 & $-1,080$ & 0,670 \\
\hline & 10 & 9 & $-0,057$ & 0,322 & 0,858 & $-0,460$ & 0,380 \\
\hline & 25 & 9 & 0,133 & 0,436 & 1,679 & $-0,400$ & 0,950 \\
\hline & 50 & 9 & $-0,008$ & 0,498 & 1,987 & $-0,940$ & 0,700 \\
\hline & 75 & 9 & 0,066 & 0,645 & 3,370 & $-0,760$ & 0,850 \\
\hline & 90 & 9 & 0,334 & 0,713 & 5,069 & $-0,540$ & 1,700 \\
\hline & 95 & 9 & $-0,051$ & 0,746 & 4,476 & $-1,520$ & 0,650 \\
\hline & 97 & 9 & 0,337 & 0,785 & 5,949 & $-1,322$ & 1,518 \\
\hline
\end{tabular}

$\mathrm{N}$ : Number, LMS: Least median of squares; NPQR: Nonparametric quantile regression.

LMS method is used mostly for construction of percentile curves. However, this method was suggested to give good results when assumptions like the homogenity of the variances and normal distribution were met. ${ }^{6.8}$ In addition, the NPQR method is more flexible than the LMS about taking different covariates to the model and it is more suitable when the parametric model assumptions are not valid. ${ }^{16}$

Our results suggest that the sum of error squares of the NPQR estimates was lower than LMS estimates in all percentile values. Especially this difference was highest at a percentile value of $10 \%$,

\begin{tabular}{|cccccccc|}
\hline \multicolumn{6}{|c|}{$\begin{array}{c}\text { TABLE 13: Weight values of Turkish girls estimated } \\
\text { from Istanbul reference values (Neyzi et al 2008). }\end{array}$} \\
\hline \multicolumn{8}{|c|}{ Girls' weight percentiles (reference values)/istanbul } \\
Age & $3 \%$ & $10 \%$ & $25 \%$ & $\mathbf{5 0} \%$ & $75 \%$ & $90 \%$ & $97 \%$ \\
\hline 6 & 15,7 & 17,0 & 18,6 & 20,6 & 22,9 & 25,3 & 27,9 \\
\hline 7 & 17,2 & 18,7 & 20,6 & 22,9 & 25,7 & 28,6 & 31,9 \\
\hline 8 & 18,9 & 20,8 & 22,9 & 25,7 & 28,9 & 32,4 & 36,5 \\
\hline 9 & 20,9 & 23,1 & 25,6 & 28,9 & 32,8 & 37,0 & 41,8 \\
\hline 10 & 23,0 & 25,6 & 28,7 & 32,6 & 37,3 & 42,3 & 48,0 \\
\hline 11 & 26,4 & 29,6 & 33,4 & 38,2 & 43,7 & 49,5 & 55,9 \\
\hline 12 & 32,0 & 35,8 & 39,9 & 45,1 & 50,9 & 56,8 & 63,1 \\
\hline 13 & 37,4 & 41,4 & 45,1 & 50,0 & 55,5 & 60,8 & 66,6 \\
\hline 14 & 41,6 & 45,0 & 48,8 & 53,3 & 58,3 & 63,2 & 68,5 \\
\hline
\end{tabular}

TABLE 14: The relationships between estimates and reference values.

\begin{tabular}{|c|c|c|c|c|c|c|}
\hline \multirow[b]{2}{*}{ Percentiles } & \multicolumn{3}{|c|}{$\begin{array}{l}\text { The relation between LMS predicted values in } \\
\text { this study and reference values in Table } 13\end{array}$} & \multicolumn{3}{|c|}{$\begin{array}{l}\text { The relation between NPQR predicted values in } \\
\text { this study and reference values in Table } 13\end{array}$} \\
\hline & $r$ & R-sqr (\%) & $p$ & $r$ & R-sqr (\%) & p \\
\hline $3^{\text {th }}$ & 0.995 & 99.0 & $<0.0001$ & 0.996 & 99.1 & $<0.0001$ \\
\hline $10^{\text {th }}$ & 0.997 & 99.4 & $<0.0001$ & 0.999 & 99.9 & $<0.0001$ \\
\hline $25^{\text {th }}$ & 0.999 & 99.7 & $<0.0001$ & 0.999 & 99.9 & $<0.0001$ \\
\hline $50^{\text {th }}$ & 0.999 & 99.8 & $<0.0001$ & 0.999 & 99.8 & $<0.0001$ \\
\hline $75^{\text {nn }}$ & 0.998 & 99.5 & $<0.0001$ & 0.999 & 99.7 & $<0.0001$ \\
\hline $97^{\text {th }}$ & 0.997 & 99.4 & $<0.0001$ & 0.998 & 99.6 & $<0.0001$ \\
\hline
\end{tabular}

LMS: Least median of squares; NPQR: Nonparametric quantile regression. 
which led to the conclusion that the NPQR method was less affected by outliers. In addition, the reference values in the Istanbul study and estimates of our models were highly correlated. ${ }^{17}$

\section{REFERENCES}

1. Gonzalez X, Miles D. Wage inequality in a developing country: decrease in minimum wage or increase in education returns. In: Fitzenberger B, Koenker R, Machado JAF, eds. Economic Applications of Quantile Regression. $1^{\text {st }} \mathrm{ed}$. Heidelberg: Physica-Verlag; 2002. p.135-45.

2. Koenker R. Quantile treatment effects. In: Chester A, Jackson M, eds. Quantile Regression. $1^{\text {th }}$ ed. Cambridge: Cambridge University Press; 2005. p.26-42.

3. Yu K, Lu Z, Stander J. Quantile regression: applications and current research areas. The Statistician 2003;52(3):331-50.

4. Koenker R, Hallock K. Quantile regression: an introduction. Journal of Economic Perspectives $2001 ; 15(4): 143-56$

5. Cole TJ, Cortina-Borja M, Sandhu J, Kelly FP, $\mathrm{Pan} \mathrm{H}$. Nonlinear growth generates age changes in the moments of the frequency distribution: the example of height in puberty. Biostatistics 2008:9(1):159-71.

6. Cole TJ, Green PJ. Smoothing reference centile curves: the LMS method and penalized likelihood. Stat Med 1992;11(10):1305-19.

7. Chen $\mathrm{L}$. An introduction to quantile regression and the QUANTREG Procedure. Statistics and Data analysis 2005; 213-230. SUGI30 Proceedings, available at children and adoles. cents. Conference on Quantitative Social Science Research Using R. available at http://www.cis.fordham.edu/QR2009/presentations/RefGrowthCharts.pdf
8. Wei Y, Pere A, Koenker R, He X. Quantile regression methods for reference growth charts Stat Med 2006;25(8):1369-82.

9. Chuchana P, Marchand D, Nugoli M, Rodriguez C, Molinari N, Garcia-Sanz JA. An adaptation of the LMS method to determine expression variations in profiling data. Nucleic Acids Res 2007;35(9):e71

10. Koenker R, Basset $G$. Regression quantiles Econometrica 1978;46(1):33-50

11. Koenker $\mathrm{R}, \mathrm{Ng} \mathrm{P}$, Portnoy $\mathrm{S}$. Quantile smoothing splines. Biometrika 1994;81(4): 673-80.

12. Yu K, Jones MC. Local linear quantile regression. The Journal of the American Statistical Association 1998:93(441):228-37.

13. Bosch RJ, Ye Y, Woodworth GG. A convergent algorithm for quantile regression with smoothing splines. Comput Stat Data Anal 1995;19(6):613-30.

14. Thompsona P, Caia Y, Moyeeda R, Reeveb $D$, Standera J. Bayesian nonparametric quantile regression using splines. Commput Stat Data Anal 2010;54(4):1138-50.

15. $\mathrm{He} X$. Quantile curves without crossing. The American Statistician 1997;51(2):186-92.

16. Takeuchi I, Le QV, Sears T, Smola AJ. Nonparametric quantile regression. Journal of $\mathrm{Ma}$ chine Learning Research 2006;7(7):1231-64 .

17. Neyzi $O$, Günöz $H$, Furman $A$, Bundak $R$, Gökçay G, Darendeliler F, et al. [Body weight, height length, head circumference and body mass index reference values for Turkish children]. Turkish Pediatric Journal 2008;51(1):1 14.

18. Royston P. A parametric model for ordinal response data, with application to estimating age-specific reference intervals. Biostatistics 2000;1(3):263-77.

19. Gasser T, Ziegler P, Seifert B, Prader A, Molinari L, Largo R. Measures of body mass and of obesity from infancy to adulthood and their appropriate transformation. Ann Hum Biol 1994;21(2):111-25.

20. Royston $P$, Wright EM. A method for estimating age-specific reference interval ('normal ranges') based on fractional polynomials and exponential transformation. Journal of the Royal Statistical Society, Series A, General 1998;161(1):79-101.

21. Heagerty P, Pepe MS. Semi-parametric estimation of regression quantiles with application to standardizing weight for height and age in US children. Applied Statistics 1999;48(4): 533-51.

22. Landajo M, Andrés J, Lorca P. Measuring firm performance by using linear and non-parametric quantile regressions. Applied Statistics 2008;57(2):227-50.

23. Min I, Kim I. A Monte Carlo comparison of parametric and non-parametric quantile regressions. Applied Economic Letters 2004; 11(2):71-4. 
Copyright of Turkiye Klinikleri Journal of Medical Sciences is the property of Ortadogh Reklam Tanitim ve Yayincilik Turizm Egitim Insaat Sanayi ve Ticaret A.S. and its content may not be copied or emailed to multiple sites or posted to a listserv without the copyright holder's express written permission. However, users may print, download, or email articles for individual use. 